\title{
車闹 Digital Commons@
}

Loyola Marymount University

LMU Loyola Law School

Journal of Catholic Education

6-1-1998

Religion and Schooling in Contemporary Amerioca: Confronting

Our Cultural Pluralism, edited by Thomas C. Hunt \& James C.

Carper

Gerald M. Cattaro

Follow this and additional works at: https://digitalcommons.Imu.edu/ce

\section{Recommended Citation}

Cattaro, G. M. (1998). Religion and Schooling in Contemporary Amerioca: Confronting Our Cultural Pluralism, edited by Thomas C. Hunt \& James C. Carper. Journal of Catholic Education, 1 (4). http://dx.doi.org/ $10.15365 /$ joce. 0104112013

This Book Review is brought to you for free with open access by the School of Education at Digital Commons at Loyola Marymount University and Loyola Law School. It has been accepted for publication in Journal of Catholic Education by the journal's editorial board and has been published on the web by an authorized administrator of Digital Commons at Loyola Marymount University and Loyola Law School. For more information about Digital Commons, please contact digitalcommons@lmu.edu. To contact the editorial board of Journal of Catholic Education, please email JCE@nd.edu. 


\title{
RELIGION AND SCHOOLING IN CONTEMPORARY AMERICA: CONFRONTING OUR CULTURAL PLURALISM
}

THOMAS C. HUNT \& JAMES C. CARPER, EDS. GARLAND PRESS, 1997.

\author{
Reviewed by Gerald M. Cattaro
}

Girea irded with well-documented essays, Hunt and Carper transport their readers into a land flowing with milk and honey. Their volume is a rich source of research into the paradoxes which religion and schooling present in contemporary America. They have crafted the ideas of scholars and practitioners such as Kniker. Randall, Cooper, Guare, Shaughnessy, Davis, and Guerra into a cohesive volume. In it they demonstrate the contexualization of religion and schooling not only in America, as the title suggests, but in the global community as well. As if walking through a labyrinth, the reader is enmeshed in the historical, legal, social, and ideological developments of the compelling issues of church and state dysfunction. In effect. contents of the text confirm the old proverb that religion is a journey and not a destination.

The volume of eight chapters focuses on religion and schooling. Religion and its place in the public sphere of education and religiously affiliated schools are the central themes addressed.

Charles Kniker's work comprises the first two chapters. which are devoted to issues of pluralism, religion in the curriculum, and religious practices in public schools. The proponents of religious accommodation in the public schools try to avoid violating the First Amendment's establishment and free exercise clauses. Attention to these concerns is immediately brought to the forefront by Kniker, who directs us to inquire relative to the concept of objectivity and religion in public schooling. In 1963 (Abington 1: Schempp/Murry 1: Curlett) the word "objective" was defined by Justice Tom Clark, who in the majority decision stated: "Nothing we have said here indicates that such study of the Bible or religion, when presented objectively as part of a secular program of education, may not be effected consistently with the First Amendment" (p. 7).

In the same case, Justice Goldberg clarifies the Court's stance on objectivity by making a distinction between teaching about religion and the teaching of religion. This distinction supports an appropriate inclusion of religious ideas, events. and institutions in the public school curriculum as knowledge for understanding rather than for belief. Kniker foresees an increasing challenge to Constitutional interpretations and opinions which prescribe a strong exclusion of religion from public education. These chapters are important and deserve to be buttressed with ongoing dialogue. Concern for religion in 
our nation's public schools is often overlooked by those who involve themselves with religious affiliated schooling.

Pivotally placed in chapter three is Randall's excellent discussion of culture. religion, and education. At first. one is tempted to read the work as a tennis match: in the first set, religion in public education vs. objectivity and, in the second, religious affiliated schools vs. challenge. Perceive it instead as a love affair that the nation has with religion and religiously affiliated schools. The objectivity and challenge presented by the Constitution then become relational and not confrontational.

A major portion of this volume is devoted to the discussion of religiously affiliated schools, where the establishment and free exercise clauses do not present problems of the same magnitude and scope as in public education. Accordingly, this second section deals with the notion of challenge. The challenge of politics, law, and economics pervades the religious school nationally and globally. In this section, the editors include essays which focus on issues of finance and religious identity. Facing the new millennium, the editors see the important contribution made by religious schools to our pluralistic society and the need to wrestle continually with these issues.

The historical account of religious schools by Randall frames the apologia for their existence in the United States. Cooper and Guare balance the significance of the sacred in religious schools with the entanglement of crosscultural. policy-related. political, and financial concerns. Their discussion of the soul of the religious school leaves one with an appetite for further discussion of the sacred. In the next essay. Shaughnessy gives a sense of vitality to the everyday law-related issues concerning management of churchrelated schools. Following the legal perspective, Davis draws upon statements of the United States Catholic bishops to describe the bishops concern for the religious development of all children in our nation. Davis nicely integrates this explication in the context of the historical development of policy and the religious school.

I recommend the book to scholars as well as to practitioners who are concerned about the cause of religion in our pluralistic society. The title is somewhat misleading, as some of the topics discussed are global as well as national in focus. Since the book is a serious invitation to further the dialogue on the topic of religion and schooling, the use of the word "confronting" in the subtitle, with its bellicose overtones, could dampen perspective readers' interest. I look forward to a subsequent edition enhanced by an increase in the number of women's voices on the issues.

Gerald M. Cattaro, formerly a Catholic school administrator, is director of the Center for Non Public Education and a visiting faculn member at Fordham University's Graduate School of Education. 
Copyright of Catholic Education: A Journal of Inquiry \& Practice is the property of Catholic Education: A Journal of Inquiry \& Practice and its content may not be copied or emailed to multiple sites or posted to a listserv without the copyright holder's express written permission. However, users may print, download, or email articles for individual use. 